\title{
NEKA PITANJA U SVEZI SA STEČAJEM NOGOMETNIH KLUBOVA U REPUBLICI HRVATSKOJ
}

\author{
UDK: 347.7 \\ Primljeno: 20. 10. 2016. \\ Pregledni rad
}

Stečaj nogometnih klubova, kao i ostalih sportskih klubova u Republici Hrvatskoj, postao je goruća tema zbog velikog broja slučajeva kada su klubovi, djelujući u pravnom obliku udruge ili kao sportska dionička društva, postali prezaduženi ili nesposobni za plaćanje. Ta tema posebno pobuđuje interes jer, iako je riječ o prepoznatljivim pravnim oblicima uređenima odgovarajućim zakonima, ipak ih u određenoj mjeri valja posebno izdvojiti s obzirom na to da se na njih u prvom redu primjenjuje Zakon o sportu, a tek podredno propisi koji inače uređuju materiju stečaja te propisi koji uređuju takva društva. U toj problematici važnu ulogu imaju i autonomna pravila, međunarodna i domaća, koja na više mjesta uređuju pitanje pravnog položaja kluba koji je u krizi. Njihov donositelj kod nas je Hrvatski nogometni savez, ekskluzivni, jedini nacionalni sportski savez koji potiče, promiče i skrbi o hrvatskom nogometnom sportu te ga predstavlja u međunarodnim odnosima. U tom smislu, uz statut HNS-a, važnu ulogu imaju HNS-ov pravilnik o licenciranju klubova, pravilnik o nogometnim natjecanjima, pravilnik o statusu igrača i registracijama, disciplinski pravilnik HNS-a te brojni drugi akti. Na međunarodnoj razini tvorac autonomnih pravila jest Međunarodni nogometni savez (FIFA) odnosno Europska nogometna unija (UEFA). S obzirom na to, treba ispitati što se događa s nogometnim klubovima kada postanu nesposobni za plaćanje ili prezaduženi. Nema dvojbe o tome da se većina odgovora nalazi u odredbama našeg Stečajnog zakona, ali potrebno je istražiti kakav je „suživot“ državnog i autonomnog prava po ovom pitanju. Pitanje stečaja nije ograničeno samo na sportske (nogometne) klubove već i na sportske saveze kao nositelje natjecanja a koji u pravilu imaju pravni status udruge te kao takvi također mogu postati subjekti stečaja. Ovo posljednje pitanje daleko je od bezazlenog jer na teritoriju jedne države može postojati samo jedna krovna sportska organizacija. Ako je nad tom tvorevinom otvoren stečaj, kako će se održavati sportska natjecanja? Spomenuta, ali i mnoga druga pitanja izazivaju dvojbe u praksi na koje nije uvijek moguće dati jednoznačan odgovor. U radu se prvenstveno provodi analiza autonomnih izvora prava, posebice onih odredaba koje predviđaju posebne, dodatne pravne učinke za slučaj kada se nad nogometnim klubom otvori stečajni postupak te se upućuje na pojedine odredbe HNS-ovog Pravilnika o licenciranju čija bi dosljedna primjena mogla imati ozbiljne posljedice za klubove u financijskoj krizi.

Ključne riječi: stečaj, udruga, sportsko dioničko društvo, licenciranje klubova, stečajni plan 


\section{UVOD}

Posebnost sporta kao fizičke ili mentalne aktivnosti koju čovjek izvodi po utvrđenom skupu pravila, u cilju natjecanja s protivnikom ili protivničkim timom, uz primjenu propisanog sistema bodovanja na osnovi kojega se utvrđuje pobjednik, ima za posljedicu to da sport ne možemo jednostavno izjednačiti s bilo kojom drugom djelatnošću već moramo uzeti u obzir sve elemente koji ,ulaze u jednadžbu“. Tako se ne smije zanemariti činjenica da se uz djelatnost sudjelovanja u sportskim natjecanjima pojavljuje i niz drugih poslova koji imaju gospodarski značaj. Posebice treba uvažiti činjenicu da u sportskim natjecanjima veliki značaj imaju momčadski sportovi u čijim natjecanjima sudjeluju klubovi - pravne osobe. U tom smislu, nogometni klubovi mogu biti ustrojeni kao udruge ili kao sportska dionička društva. Radi pravne sigurnosti, ne bi bilo dopustivo da se tim pravnim osobama samo iz razloga što sudjeluju u sportskim natjecanjima dade povlašteni položaj u odnosu na ostale pravne osobe istoga tipa. Uređenje pravnih odnosa u sportu predstavlja veliki izazov za sve koji u tome sudjeluju jer, s jedne strane, sudionicima i ostalim subjektima u sportskim natjecanjima valja dati određenu slobodu, a s druge strane treba priznati da sport i sportska natjecanja predstavljaju važnu gospodarsku djelatnost koju država ne smije u potpunosti prepustiti autonomnim pravilima. Naš je zakonodavac u najboljoj namjeri prepoznao tu činjenicu te, nakon donošenja Zakona o športu 1990. godine koji je zamijenio Zakon o fizičkoj kulturi bivše države, kontinuirano provodi veće i manje zahvate u tu materiju. Spomenuti Zakon, međutim, niti brojnim izmjenama odnosno novim verzijama ne uspijeva riješiti brojna otvorena pitanja u svezi s tumačenjem i primjenom njegovih odredaba. To je donekle i razumljivo jer sport zadire u sve pravne grane pa je pred zakonodavcem težak zadatak izrade propisa kojim će se osigurati optimalno uređenje tog područja ljudske djelatnosti. Nažalost, niti propisi koji uređuju materiju stečajnog prava nisu primjer dosljedne zakonodavne politike iako je zakonodavčev cilj uvijek bio bolje i potpunije uređenje tog područja. U ostvarenju spomenutog cilja u prethodna dva desetljeća bilo je određenih lutanja iako je naš zakonodavac i prije ulaska Republike Hrvatske u Europsku uniju započeo postupak usklađivanja kroz prihvaćanje najboljih rješenja iz stranih zakonodavstava, poglavito stečajnog prava SR Njemačke, a posao se nastavio usvajanjem rješenja iz direktiva koje donosi Vijeće Unije. Nesporno je da stečajni postupak predstavlja sudski postupak skupnog namirenja vjerovnika, unovčenjem imovine stečajnog dužnika i podjelom prikupljenih sredstava vjerovnicima. No usprkos tome, stečaj ne znači nužno i prestanak kluba jer Zakon uređuje i institut stečajnog plana, institut koji bi, po naravi stvari, mogao predstavljati dobro rješenje za nogometne klubove kod kojih su nastali stečajni razlozi jer se time osigurava njihov opstanak kao pravnih osoba - subjekata prava.

Nogometni klubovi sve češće dospijevaju u stanje krize. Glavni razlog za to jest činjenica da klubovi žele ostvariti sportski uspjeh koji će im donijeti povećanu dobit kroz povećani interes publike za praćenje utakmica, zaradu od reklama i naknade za izravne prijenose utakmica na specijaliziranim sportskim televizijskim i ostalim 
kanalima. Da bi ostvarili uspjeh, oni ulažu značajna sredstva u kupovinu igrača i poboljšanje infrastrukture. Nerijetko se takva predviđanja ne ostvare jer klubovi i uz velika ulaganja ne moraju nužno ostvariti sportski uspjeh. Govoreći načelno, postoji percepcija da su klubovi kod kojih nastanu stečajni razlozi poslovali iznad svojih mogućnosti. Tako se u preambuli Pravila UEFA-e u licenciranju i financijskom fair playu navodi kako se mora uvesti više discipline i racionalnosti u financije klubova. ${ }^{1}$ U tom smislu, nastanak stanja financijske krize kluba moglo bi se protumačiti kao posljedicu niza pogrešaka u vođenju poslova i upravljanju nogometnim klubom. Naime, klubovi troše znatna sredstva da bi ostvarili sportski uspjeh što im se vraća kroz novčane nagrade, prodaju ulaznica, suvenira te na televizijska prava. Razvidno je da postoji izravna veza između ulaganja u pribavljanje usluga kvalitetnih igrača i spomenutih pozitivnih učinaka koji imaju novčani ekvivalent. U tom kontekstu raspravlja se o svojevrsnom paradoksu: rastu prihodi klubova, ali je primjetan pad ukupnog financijskog rezultata zbog sve viših iznosa poslovnih rashoda u kojima su najveća stavka plaće igrača. ${ }^{2}$ Zbog prirode sportskog natjecanja, procjena o ulaganju uvijek nosi rizike koji bi u nekoj drugoj grani poslovanja bili ocijenjeni nerazumno previsokima, praktički hazardnima. Naime, financijska kriza koja dovodi do nastanka stečajnih razloga može biti i posljedica spleta nepredviđenih okolnosti. ${ }^{3}$ Tom stanju zasigurno ne pomaže niti činjenica da osobe ovlaštene za vođenje poslova i zastupanje tih klubova nerijetko ne posjeduju ni dostatna znanja niti vještine za uspješno obavljanje te funkcije ili su pak spremne na nerazumno visoke rizike jer u slučaju neuspjeha neće osobno, svojom imovinom, odgovarati za nagomilane obveze. ${ }^{4}$ To je opća pojava koja nije imanentna samo klubovima u Republici Hrvatskoj, već je prisutna u svim zemljama gdje nogomet predstavlja „najvažniju sporednu stvar na svijetu“.

Kod krize nogometnih klubova pojavljuju se posebne značajke koje se rijetko pojavljuju u slučaju krize klasičnog trgovačkog društva ili udruge. Prvo, i onda kada je klub u financijskoj krizi, ipak može zadržati pozornost i podršku navijača, što je vidljivo i kod nas, posebice u slučaju NK Hajduk ili u Europi (npr. klub Schalke 04 u SR Njemačkoj), što znači da može računati na prihode od ulaznica. Drugo, mladi i talentirani igrači koji još nisu stvorili reputaciju spremni su nastupati za neki klub i onda kada im taj klub ne može isplatiti visoke iznose za njihovu uslugu igranja jer tako dospijevaju „,u izlog“ te će dobiti ponudu od drugog kluba koji će im osigurati bolje uvjete. U smislu bilance, igrači predstavljaju dugotrajnu

1 UEFA Club Licensing and Financial Fair Play Regulations, čl. 2, st. 2. Tekst Pravilnika dostupan na http://uefa.to/1JwQygx, pregledano 1. XII. 2016.

2 Dietl, H.; Franck, E., „Governance Failure and Financial Crisis in German Football“, Journal of Sports economics, vol. 8, br. 6 (2007.), str. 663.

3 Primjerice 2002. godine neočekivana propast trgovačkog društva ITV Digital, koje je bilo nositelj prava na prijenose utakmica engleskih liga, za posljedicu je imala da su engleski klubovi izgubili 10-20 \% godišnjih prihoda. U razdoblju od jedne godine od tog događaja, nad 12 klubova otvoren je stečajni postupak. Szymanski, S., Insolvency in English professional football: Irrational Exuberance or Negative Shocks?, str. 3. Dostupno na http://www.soccernomics-agency.com/, pregledano 1. XII. 2016.

Andreff, W., „A Financial Crisis Rooted in Weak Governance“, Journal of Sports Economics, vol. 8, 6 (2007.), str. 9. 
nematerijalnu imovinu, ali ujedno predstavljaju daleko najvažniju stavku poslovnih prihoda kluba. Treće, bitan dio imovine mogu predstavljati sportski stadion i ostala prateća infrastruktura, pod uvjetom da doista spadaju u vlasništvo kluba što kod nas najčešće, nažalost, i nije slučaj, već nogometni klubovi uglavnom imaju pravo (višegodišnjeg) korištenja spomenute infrastrukuture, a njezini vlasnici su gradovi ili jedinice lokalne uprave i samouprave. No ipak, zbog značaja koji klubovi imaju za sredinu u kojoj djeluju, javnopravni vlasnici sportskih objekata klubovima najčešće daju široka prava u pogledu njihova komercijalnog a ne samo sportskog iskorištavanja.

Iz navedenoga već je vidljivo da stečaj koji dovodi do konačne likvidacije pravne osobe (tzv. likvidacijski stečaj) u slučaju nogometnog kluba nije najbolje rješenje jer samo klub koji i dalje postoji može ostvariti prihode kroz naknade za transfer igrača, a može računati i na budući dobitak kroz naknadu za razvoj igrača i/ili iznos koji se odvaja kao solidarni doprinos. Ako je nad klubom proveden likvidacijski stečaj, iznos iz naknade za razvoj i solidarni doprinos pripada Hrvatskom nogometnom savezu što je rješenje koje ne odgovara stečajnim vjerovnicima kluba jer su time lišeni prava koja bi inače imali prema odredbama Stečajnog zakona.

Kod nas pitanje krize nogometnih klubova nije isključivo pravni problem već nerijetko dobiva i političku dimenziju jer se klubovi financiraju sredstvima subjekata javnoga prava što, doduše, nije neuobičajena praksa ni u drugim državama. ${ }^{5}$ Osnovu financiranja sporta tako čine prihodi što ih pravne i fizičke osobe koje obavljaju sportsku djelatnost ostvare obavljanjem sportske djelatnosti, članarine koju ostvaruju sportske udruge, dio prihoda od priređivanja igara na sreću i sredstva kojima jedinice lokalne i područne (regionalne) samouprave i država pomažu obavljanje sportskih djelatnosti. Štoviše, temeljem odredaba o obveznom preoblikovanju iz Zakona o sportu, Republika Hrvatska prenijela je svoje tražbine prema sportskim klubovima-udrugama na jedinice lokalne samouprave koje su time gotovo prisilno postale dioničari tih klubova. U takvim slučajevima javnost (navijači) nerijetko od spomenutih osoba javnoga prava zahtijeva mnogo više od nominalne obveze lojalnog postupanja prema društvu (klubu) i drugim dioničarima.

\section{PRAVNI OKVIR U KOJEM SE ODVIJA NOGOMETNO NATJECANJE I DRŽAVNI IZVORI PRAVA}

Pitanje izvora prava i njihove hijerarhije nesumnjivo predstavlja ključni problem pravnog uređenja nogometa. Izvore treba podijeliti na dva pravna područja - državno i autonomno pravo. Za područje sporta općenito, a time i nogometa, može se reći da postoji poveznica sa svim granama prava, ali vezano uz temu rada,

\footnotetext{
Takav model na snazi je, primjerice, u Švedskoj gdje različiti subjekti javnog prava doprinose s iznosima od 25-50 \% predviđenog proračuna nogometnog kluba. Carlsson, B., „Insolvency and the domestic jurisdiction of football in Sweden“, Soccer \& Society, vol. 10, br. 3-4 (2009.), str. 479.
} 
kao izvore državnog prava valja posebno izdvojiti Ustav $\mathrm{RH},{ }^{6}$ Zakon o sportu, ${ }^{7}$ Zakon o udrugama, ${ }^{8}$ Zakon o trgovačkim društvima, ${ }^{9}$ Stečajni zakon, ${ }^{10}$ Zakon o računovodstvu. ${ }^{11}$ Već se tu postavlja pitanje hijerarhije u primjeni spomenutih zakona. S druge strane, postoji niz autonomnih izvora prava vezanih za temu rada, a to su Statut HNS-a, HNS-ov Pravilnik o licenciranju, Odluka o sustavu stalnih natjecanja, Pravilnik o nogometnim natjecanjima, Propozicije natjecanja po ligama, Pravilnik o statusu igrača i registracijama, Poslovnik o radu Skupštine HNS-a, Pravilnik o radu Izvršnog odbora HNS-a i njegovih organa, Pravilnik o radu Arbitražnog suda, Pravilnik o Arbitraži HNS-a, Odluka o visini naknade za treniranje i razvoj igrača, Odluka o iznosima pristojbi te međunarodni autonomni akti, kao što je primjerice UEFA-in Pravilnik o licenciranju klubova i financijskom fair playu. ${ }^{12}$ Između spomenuta dva pravna područja vlada varljivo primirje koje, međutim, nosi ozbiljnu posljedicu - stvara se stanje pravne nesigurnosti. Za početak, vrijedi naglasiti da autonomni izvori prava moraju biti u skladu s Ustavom, prisilnim propisima i moralom društva. Prisilni (kogentni) propis jest propis koji obvezuje na jedno čvrsto određeno ponašanje koje zakonodavac smatra posebno važnim za pravni poredak, za pravnu sigurnost i za vladavinu prava, ponašanje koje svakako hoće postići.

Nakon Ustava RH, glavni izvor prava jest Zakon o sportu ${ }^{13}$ koji predstavlja lex specialis te na nekoliko mjesta uređuje pitanje stečaja. Pitanje stečaja prvenstveno veže uz sportske udruge i sportska dionička društva (iako je moguć i stečaj sportske ustanove, ali one ne sudjeluju u sportskim natjecanjima). Zakon dodatno uređuje neka pitanja ustroja sportskih udruga-klubova za natjecanje ${ }^{14}$ te sportskih dioničkih društava ${ }^{15}$ dok se za ostalo primjenjuju zakoni koji inače uređuju te pravne oblike.

Za našu temu značajna je okolnost da Zakon uređuje status i ovlasti nacionalnih sportskih saveza pa time i Hrvatskog nogometnog saveza jer predviđa da svaki nacionalni savez uređuje sustav natjecanja u sportu za koji je osnovan i druga pitanja za čije je uređivanje ovlašten prema odredbama ovoga Zakona, te donosi pojedinačne akte kada je za to ovlašten. Nacionalni sportski savez općim

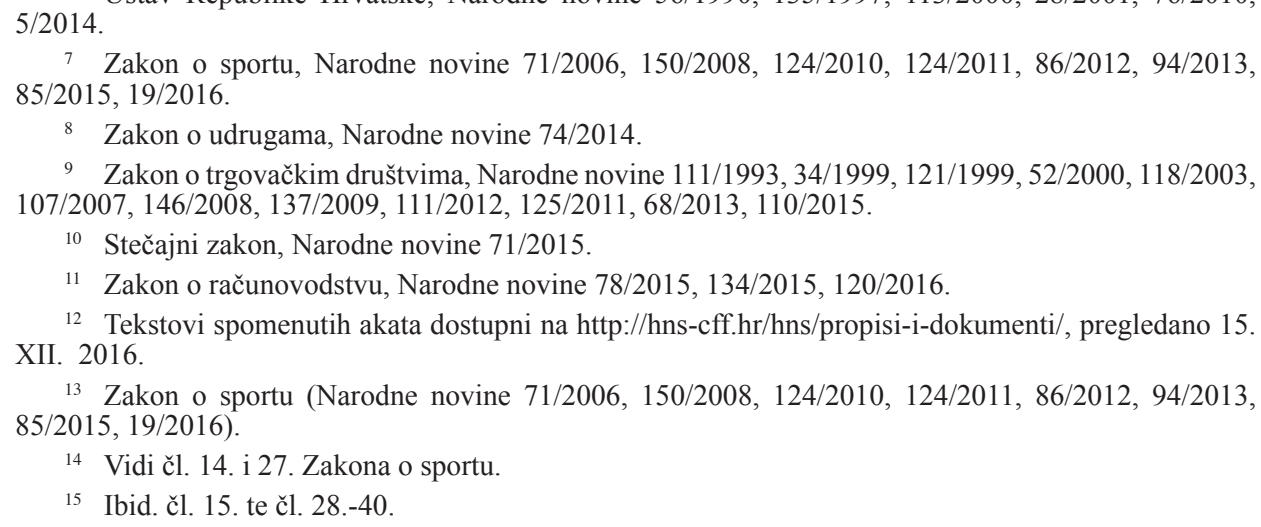

7 Zakon o sportu, Narodne novine 71/2006, 150/2008, 124/2010, 124/2011, 86/2012, 94/2013, $85 / 2015,19 / 2016$

8 Zakon o udrugama, Narodne novine 74/2014.

9 Zakon o trgovačkim društvima, Narodne novine 111/1993, 34/1999, 121/1999, 52/2000, 118/2003, 107/2007, 146/2008, 137/2009, 111/2012, 125/2011, 68/2013, 110/2015.

10 Stečajni zakon, Narodne novine 71/2015.

11 Zakon o računovodstvu, Narodne novine 78/2015, 134/2015, 120/2016.

12 Tekstovi spomenutih akata dostupni na http://hns-cff.hr/hns/propisi-i-dokumenti/, pregledano 15. XII. 2016.

13 Zakon o sportu (Narodne novine 71/2006, 150/2008, 124/2010, 124/2011, 86/2012, 94/2013, $85 / 2015,19 / 2016)$.

14 Vidi čl. 14. i 27. Zakona o sportu.

15 Ibid. čl. 15. te čl. 28.-40.

6 Ustav Republike Hrvatske, Narodne novine 56/1990, 135/1997, 113/2000, 28/2001, 76/2010, 
aktima uređuje i uvjete koje moraju ispunjavati sportski klubovi da bi stekli profesionalni status, registraciju sportaša, njihova prava i obveze, pravo nastupa stranih sportaša za hrvatske sportske klubove, stegovne odgovornosti sportaša te prava i obveze sportskih sudaca i zdravstvenih djelatnika. ${ }^{16}$ Jasno se navodi da je Hrvatski olimpijski odbor (HOO) najviša nevladina nacionalna sportska udruga u koju se udružuju nacionalni sportski savezi, a pri HOO-u djeluju Vijeće sportske arbitraže i Sportsko arbitražno sudište koje djeluje kao prizivno tijelo protiv odluka sportskih saveza. ${ }^{17}$

Spomenutim Zakonom o sportu posebno se uređuje status profesionalnih sportskih (a time i nogometnih) klubova, a tu je riječ o klubovima koji su osnovani radi obavljanja sportske djelatnosti sudjelovanja u sportskom natjecanju, ako više od $50 \%$ registriranih sportaša tog kluba u seniorskoj konkurenciji ima sklopljen ugovor o profesionalnom igranju ili ugovor o radu sa sportskim klubom, u odnosu na broj prijavljenih sportaša za natjecateljsku godinu na listi koju vodi nacionalni sportski savez. Kako je već istaknuto, profesionalni nogometni klubovi mogu biti i u formi udruge, ${ }^{18}$ a dužni su, nakon upisa u registar profesionalnih klubova, provesti reviziju pri čemu je zadaća revizora, između ostaloga, utvrditi jesu li ostvareni uvjeti za pokretanje stečajnog postupka sukladno posebnim propisima, odnosno uvjeti za obvezno preoblikovanje u sportsko dioničko društvo. Valja pripomenuti da se primjenom istih odredaba može provesti i dragovoljno preoblikovanje klubaudruge u sportsko dioničko društvo. Iz navedenih odredaba postaje jasno da sportski klubovi-udruge uživaju posebne (ne)zaslužene povlastice u odnosu na udruge koje nisu osnovane radi obavljanja sportske djelatnosti jer se kod prvih stečajni postupak provodi tek onda ako nije uspjelo njihovo preoblikovanje, a takva se mogućnost ne daje ostalim subjektima nad kojima se može otvoriti stečajni postupak. I ostale odredbe koje uređuju materiju obveznog preoblikovanja taj problem samo dodatno produbljuju. ${ }^{19}$

U okviru revizije moraju se utvrditi popis i procjena vrijednosti imovine, popis svih tražbina prema profesionalnom sportskom klubu, navedenih prema vrstama vjerovnika i njihovoj visini, pregled poslovanja profesionalnoga sportskog kluba $\mathrm{u}$ proteklih pet godina, uz posebno iskazane prihode i rashode profesionalnoga sportskog kluba u tome razdoblju, pobliži opis na što se oni odnose te godišnje

16 Ibid. čl. 47. st. 4. i 6.

17 Ibid. čl. 51. i 52.

18 Prema trenutnom stanju, u registar profesionalnih klubova koji vodi Ministarstvo upisano je 14 nogometnih klubova, a to su NK Zagreb, NK Inter Zaprešić, HNK Rijeka s.d.d., NK Osijek s.d.d., NK Slaven, HNK Šibenik s.d.d., HNK Hajduk s.d.d., GNK Dinamo, NK Istra 1961 s.d.d., NK Zadar s.d.d., NK Lokomotiva, RNK Split s.d.d. i NK Hrvatski Dragovoljac. U međuvremenu izbrisano je ukupno 8 klubova što ne znači da su ti klubovi prestali postojati već su samo izgubili status profesionalnih klubova.

19 Tako prema čl. 42. Zakona o sportu, Republika Hrvatska (što uključuje i Pravne osobe u kojima Republika Hrvatska ima većinski udio ili većinsko pravo glasa) može prenijeti svoje tražbine prema sportskim klubovima-udrugama za natjecanje, koje su obvezne preoblikovati se u s.d.d., na jedinicu lokalne samouprave, u kojoj je sjedište sportskog kluba-udruge za natjecanje, prema posebnom ugovoru o prijenosu u kojem će se utvrditi prava i obveze ugovornih strana. To ima za posljedicu da nogometni klubovi time nisu postali privatizirani u pravom, užem smislu te riječi jer će većinski članovi tih društava postati jedinice lokalne samouprave. 
račune dobiti i gubitka profesionalnoga sportskog kluba u tome razdoblju, procjenu na razini jedne godine, prava igranja na javnoj sportskoj građevini za koju profesionalni sportski klub ima koncesiju te prema pravilima struke utvrditi vrijednost tražbina prema profesionalnom sportskom klubu, a pri čemu osobito treba voditi računa o vrijednosti imovine i obveze profesionalnoga sportskog kluba, o sposobnosti profesionalnoga sportskog kluba da podmiruje svoje dospjele obveze, o okolnosti je li profesionalni sportski klub u proteklom razdoblju uredno podmirivao svoje dospjele obveze, o tome može li, u kojem roku i na koji način profesionalni sportski klub bez dodatnih ulaganja uopće podmiriti svoja dugovanja te kakvo bi, bez dodatnih ulaganja, bilo očekivano poslovanje profesionalnoga sportskog kluba u budućnosti, što se utvrđuje prema razumnim gospodarskim mjerilima. ${ }^{20} \mathrm{U}$ svrhu praćenja obavljanja djelatnosti profesionalnih sportskih klubova, Zakonom se formiralo posebno stručno tijelo - Povjerenstvo za profesionalne sportske klubove. Obveza preoblikovanja sportskog kluba-udruge u sportsko dioničko društvo postoji uvijek kada je riječ o profesionalnom sportskom klubu a stekli su se uvjeti za pokretanje stečajnog postupka. Okolnost postojanja stečajnog razloga može se utvrditi spomenutom posebnom revizijom, ali i na temelju drugih isprava - računa dobiti i gubitka, plana poslovanja te godišnjih financijskih i revizorskih izvješća; te isprave profesionalni klub jednom godišnje podnosi Povjerenstvu.

Povjerenstvo predlaže pokretanje stečajnog postupka ako sportski klub-udruga za natjecanje ne provede postupak preoblikovanja u s.d.d., iako se utvrdilo da to mora učiniti, ili pak ako preoblikovanje nije uspjelo. Ministarstvo znanosti, obrazovanja i sporta, na prijedlog spomenutog Povjerenstva (za profesionalne sportske klubove), po službenoj dužnosti, podnosi prijedlog za otvaranje stečajnog postupka. Time se u odnosu na Stečajni zakon proširuje krug subjekata na čiji se prijedlog može pokrenuti stečajni postupak. ${ }^{21}$ Klub-udruga za natjecanje, uz pravne učinke otvaranja stečajnog postupka uređene našim Stečajnim zakonom, „trpi posljedice“ sukladno pravilima Hrvatskog nogometnog saveza, o čemu će više biti riječi kasnije u radu.

Nesumnjivo je da za temu rada valja dati osvrt na pojedine odredbe našeg Stečajnog zakona. Da bi se stečajni postupak otvorio, sud mora utvrditi postojanje stečajnih razloga u koje spadaju nesposobnost za plaćanje i prezaduženost. U prvom slučaju, dužnik ne može trajnije ispunjavati svoje obveze; u drugom je imovina dužnika jednostavno manja od postojećih obveza, a nema u konkretnom slučaju razumne osnove za zaključak da će dužnik u budućnosti nastaviti uredno ispunjavati svoje obveze po dospijeću. Spomenuti razlozi mogu nastati i kod nogometnih klubova koji po ustroju mogu biti udruge ili sportska dionička društva, a iz Stečajnog zakona jasno proizlazi da ti pravni oblici mogu biti predstečajni ili stečajni dužnici jer nisu izrijekom isključeni od primjene Zakona. ${ }^{22}$ Vrijedi pripomenuti da je Hrvatski nogometni savez po svom ustroju udruga pa bi se i nad njim mogao provesti stečajni postupak.

20 Vidi čl. 40. Zakona o sportu.

21 Vidi čl. 109. i 110. našeg Stečajnog zakona (Narodne novine 71/2015).

22 Vidi čl. 3. Stečajnog zakona. 
Uz tzv. likvidacijski stečajni postupak, koji ima za posljedicu da se nakon diobe dužnik pravna osoba briše iz odgovarajućeg registra i prestaje postojati, naš Zakon uređuje i institut stečajnog plana koji predstavlja intrigantno pravno sredstvo koje klubovima u financijskoj krizi može omogućiti nastavak poslovanja odnosno obavljanje sportske djelatnosti uz očuvanje njihove pravne osobnosti. Tim prije što je i naš Zakonodavac u Nacrtu prijedloga Stečajnog zakona istaknuo kako dokazi upućuju na to da poduzetnici uče iz svojih pogrešaka i da su općenito puno uspješniji u svojem drugom pokušaju poslovanja. Zbog navedenoga, Europska komisija je 12. ožujka 2014. donijela Preporuke o novom pristupu stečaju i insolventnosti poduzetnika kojima je utvrdila niz općih načela za nacionalne postupke insolventnosti. Cilj je odvratiti pozornost od likvidacije te je preusmjeriti na poticanje održivih poduzetnika na restrukturiranje u ranoj fazi kako bi se spriječila insolventnost i omogućio nastavak poslovanja. Nastavno na preporuke Europske komisije, stečajnim planom kao odrazom jednog od temeljnih načela vjerovnika - načela vjerovničke autonomije, ponovno bi se vjerovnicima omogućilo da u stečajnom postupku odstupe od pravila zakona koja uređuju unovčenje imovine stečajnog dužnika te na drugačiji način urede način i visinu namirenja svojih tražbina. Isto tako, vjerovnicima se omogućava donošenje odluke o tome hoće li se poslovanje dužnika nastaviti ili obustaviti. ${ }^{23}$ Prema tome, stečajni plan je pravni instrument stečajnoga prava koji predviđa „financijski predah“ posrnulom poslovnom subjektu, a tako i nogometnom klubu. Tu je riječ o skupini pravnih i ekonomskih mjera koje omogućuju klubu u financijskim poteškoćama, a za koji postoje realni izgledi da uspješno nastavi s poslovanjem, da u praksi to i provede, bez pritiska vjerovnika koji inzistiranjem na naplati svojih tražbina, onemogućuju stečajnom dužniku nastavak i odvijanje poslovanja. ${ }^{24}$

Za provedbu stečajnog plana nužna je pretpostavka da je nastupio jedan od stečajnih razloga te da je tim povodom podnesen sudu zahtjev za otvaranjem stečajnog postupka koji naposljetku bude i otvoren. Stečajni plan ima pravo sudu podnijeti stečajni upravitelj. Dužnik koji podnosi prijedlog za otvaranje stečajnoga postupka može predložiti smjernice za donošenje stečajnoga plana o kojima se na izvještajnom ročištu očituju stečajni upravitelj i stečajni vjerovnici. ${ }^{25}$ Stečajni plan ima izgleda za uspjeh ako ga prihvate vjerovnici, što u praksi i nije bio slučaj, ali zbog posebnih značajki sportskih, posebice nogometnih klubova takav put mogao bi postati praksa barem za klubove koji sudjeluju u najvišim razinama natjecanja. Kad rješenje o potvrdi stečajnog plana postane pravomoćno, sud će donijeti odluku o zaključenju stečajnoga postupka.

Ako se nad klubom provede likvidacijski stečajni postupak, šanse za barem i djelomično namirenje vjerovnika opadaju jer najveću vrijednost kluba predstavljaju igrači, odnosno buduća dobit koja se može ostvariti njihovim transferima. Prema

23 Vidistr. 1.i4.Nacrta, dostupnonahttps://vlada.gov.hr/UserDocsImages//Sjednice/2014/...//200\%20 -\%201.pdf, pregledano 15. XII. 2016.

24 Vidi Akšamović, D., Jelinić, Z., „Aktualna pitanja športa u Republici Hrvatskoj - preoblikovanje ili stečaj profesionalnih športskih klubova?“, Pravo u gospodarstvu, vol. 47, br. 4 (2008.), str. 855.

25 Vidi čl. 304. Stečajnog zakona. 
Pravilniku FIFA-e o statusu i transferu igrača, okolnost da igrač nije primio plaću 3 mjeseca uzastopno predstavlja opravdani razlog za jednostrani raskid ugovora pa ako klub brzo ne reagira, igrač postaje slobodan i klub ne može ostvariti dobit od transfera. Jasno je da stečajni upravitelj može ugovore održati na snazi, ali pitanje je hoće li na to pristati igrači. ${ }^{26}$ Nadalje, klubu koji više ne postoji ne može se isplatiti naknada za treniranje niti naknada s naslova solidarnog doprinosa za sudjelovanje u treniranju i obrazovanju igrača. Savez ima pravo primiti naknadu za treniranje koja bi u načelu trebala biti plaćena jednom od njegovih pridruženih klubova, ako on može dokazati da je odnosni klub - za koji je profesionalac bio registriran i koji ga je trenirao - u međuvremenu prestao sudjelovati u organiziranom nogometu i/ili više ne postoji zbog, posebice, stečaja, likvidacije, raspuštanja ili gubitka članstva. Ova naknada je namijenjena programima razvoja nogometa mlađih dobnih uzrasta u odnosnom savezu (savezima). ${ }^{27}$ To se pokazalo u slučaju Marka Roga koji je iz GNK Dinamo prešao u talijanski klub Napoli, o čemu će posebno biti riječi u zaključku rada. Iznos od cca 400.000 eura, koji bi inače pripao klubu NK Varteks iz Varaždina, pripao je HNS-u koji ga može slobodno upotrebljavati za ostvarivanje proklamiranih ciljeva. ${ }^{28} \mathrm{Ne}$ valja zanemariti ni društveno-psihološke učinke gašenja kluba s dugom tradicijom. Iz tih razloga, mogućnost preustroja kluba kroz stečajni plan nameće se kao logično rješenje. Uz prethodno opisano, otvaranje stečajnog postupka nad nogometnim klubovima ima i druge posljedice koje su uređene autonomnim aktima HNS-a. Analiza različitih pravilnika, a posebice Pravilnika o licenciranju, pokazuje da bi odluka vjerovnika o nastavljanju poslovanja u stečaju praktički ostala bez učinka jer je dvojbeno može li u tim uvjetima klub steći odnosno zadržati licencu za natjecanje.

\section{AUTONOMNI IZVORI PRAVA VEZANI ZA NOGOMETNU IGRU U KONTEKSTU STEČAJA KLUBA}

Načelno, nogometni klubovi nisu organizatori ni nositelji natjecanja jer se kod organizacije natjecanja otvaraju brojna posebna pitanja koja nastaju zbog sudjelovanja velikog broja klubova u natjecanju. Stoga su se u okviru država formirali posebni sportski savezi pa je kod nas nogometno natjecanje u domeni Hrvatskog nogometnog saveza jer je, prema čl. 1. Statuta, ${ }^{29}$ Hrvatski nogometni savez jedini nacionalni sportski savez koji potiče, promiče i skrbi o hrvatskom nogometnom sportu, skrbi se o nacionalnim nogometnim ekipama, te ga predstavlja

26 Vidi čl. 14. spomenutog Pravilnika FIFA-e. Tekst u prijevodu dostupan na http://hns-cff.hr/hns/ propisi-i-dokumenti/, pregledano 15. XII. 2016.

27 Vidi Dodatak 4, čl. 3., st. 3. odnosno Dodatak 5, čl. 2., st. 3. Pravilnika FIFA-e. Usp. čl. 65. HNSovog Pravilnika o statusu igrača i registracijama.

28 Vidi novinsku vijest dostupnu na http://varazdinski.rtl.hr/sport/varteks-ostaje-bez-naknade-zatransfer-marka-roga-3-miijuna-kuna-idu-hns-u, pregledano 15. XII. 2016.

29 Statut Hrvatskog nogometnog saveza (Glasnik HNS-a br. 16/14). Tekst spomenutog Statuta dostupan na http://hns-cff.hr/hns/propisi-i-dokumenti/, pregledano 15. XII. 2016. 
u međunarodnim odnosima. Ciljevi su HNS-a promicanje i unapređenje nogometnog sporta u Republici Hrvatskoj te predstavljanje hrvatskog nogometa u inozemstvu, a spomenute ciljeve, između ostaloga, ostvaruje organiziranjem i provođenjem sustava natjecanja, uređivanjem odnosa u vezi s registracijom igrača i klubova, statusa nogometaša i drugih djelatnika, disciplinskom odgovornosti igrača i drugih nogometnih djelatnika, uređivanjem pitanja koja se odnose na utvrđivanje uvjeta što ih nogometni klub mora ispunjavati za obavljanje nogometnog sporta. ${ }^{30}$

Po svom pravnom obliku Savez je udruga, što znači da se i nad njim može provesti stečajni postupak. To može stvoriti apsurdnu situaciju da prestane postojati udruga koja je nositelj natjecanja za pojedini sport. U slučaju prestanka rada Saveza, imovina Saveza prelazi u vlasništvo sportske udruge koja će nastaviti djelatnost radi promicanja i razvitka nogometa na području Republike Hrvatske, a ako nema takve sportske udruge, imovinu Saveza preuzet će Republika Hrvatska. ${ }^{31}$ Nažalost, na ovom mjestu ne možemo zaključiti da je takav slučaj nezamisliv i predmet teorije jer se kod nas već dogodio. ${ }^{32}$

Savez može obavljati gospodarske djelatnosti, a to su izdavačka djelatnost, trgovina, davanje u zakup poslovnog prostora, te može stjecati pokretnu i nepokretnu imovinu, a može osnovati i trgovačko društvo. ${ }^{33}$

Savez ostvaruje prihode jednim dijelom vlastitom djelatnošću i s tim sredstvima slobodno raspolaže. Savez se financira i iz sredstava koje Republika Hrvatska osigurava u Državnom proračunu, te putem Hrvatskog olimpijskog odbora doznačava Savezu, uplatom članarina i pristojbi, sponzorskih ugovora, novčanih kazni koje su izrekla nadležna tijela Saveza, dobrovoljnih priloga i darova i drugih dopuštenih izvora (čl. 76. i 77. Statuta).

Članovi su Saveza 20 nogometnih saveza u županijama, nogometni savez Grada Zagreba, sportski savezi gradova i nogometni klubovi, pri čemu su nogometni klubovi i sportski savezi gradova posredni članovi Saveza.

Savez, između ostaloga, mora voditi računa o organiziranju i provođenju sustava natjecanja, uređivanja odnosa u vezi s registracijom koji se tiču registracije igrača i klubova, statusa nogometaša i drugih djelatnika, o disciplinskoj odgovornosti igrača i drugih nogometnih djelatnika, uređivanju pitanja koja se odnose na utvrđivanje uvjeta što ih nogometni klub mora ispunjavati za obavljanje nogometnog sporta. Tu je svakako važan element pitanje ispunjavaju li klubovi i financijske kriterije za sudjelovanje u natjecanju što je svakako dovedeno u pitanje ako je kod nogometnog kluba nastao stečajni razlog.

30 Vidi čl. 1. i 12. Statuta HNS-a.

31 Vidi čl. 94. Statuta HNS-a.

32 Riječ je o stečaju Hrvatskog odbojkaškog i Hrvatskog golf saveza. Vidi Kačer, H., „Novi skandal u sportskom pravu“, članak dostupan na http://www.iusinfo.hr/DailyContent/Topical.aspx?id=7830, pregledano 16. XII. 2016.

33 Vidi čl. 81. i 82. Statuta HNS-a. 
Savez je ovlašten donositi autonomne pravne akte koji time postaju izvor prava za nogometnu igru. Tako, prema HNS-ovom Pravilniku o nogometnim natjecanjima, ${ }^{34}$ ako klub koji je svojim plasmanom stekao pravo igranja na višem stupnju natjecanja ne ispunjava uvjete za taj stupanja natjecanja ili odustane od prava korištenja prava igranja na višem stupnju natjecanja, ustupa mjesto drugom klubu. ${ }^{35} \mathrm{U}$ smislu ove odredbe, u normalnim okolnostima o eventualnom odustanku od prava igranja na višem stupnju natjecanja odlučivala bi skupština udruge odnosno glavna skupština sportskog dioničkog društva jer je riječ o odlukama koje ne spadaju u redovito poslovodstvo. Međutim, ako je nad klubom otvoren stečajni postupak, o tome na izvještajnom ročištu odlučuju vjerovnici. ${ }^{36}$

Nadalje, klub koji odustane od prvenstvenog natjecanja pada u najniži stupanj natjecanja, bez obzira na do tada postignute rezultate u natjecanju, a smatrat će se da je klub odustao od natjecanja ako neka od njegovih momčadi neopravdano nije odigrala dvije utakmice tijekom natjecanja u istoj natjecateljskoj godini. ${ }^{37} \mathrm{Klub}$ kojem bude prema Pravilniku o licenciranju klubova opozvana licenca, zato što je prije početka natjecanja odustao od licence, igrat će u jednom stupnju natjecanja nižem od onoga u kojem je igrao prethodne natjecateljske godine pod uvjetom da je odustao od licence najkasnije 30 dana prije početka prvenstvenog natjecanja. Ako je pak odustao od licence u razdoblju kraćem od 30 dana od početka prvenstvenog natjecanja, igrat će na najnižoj razini natjecanja. ${ }^{38}$ Ako je nad klubom otvoren stečajni postupak, o pitanju daljnjeg sudjelovanja u natjecanjima i pristupanju postupku licenciranja odlučuju na izvještajnom ročištu stečajni vjerovnici jer je tu zapravo riječ o nastavljanju poslovanja. ${ }^{39}$

Akoklub-udrugane provede postupak obveznog preoblikovanjaili preoblikovanje ne uspije, nadležno Ministarstvo podnosi prijedlog za otvaranje stečajnog postupka, a na kraju natjecateljske godine prelazi u prvi niži stupanj natjecanja u odnosu na stupanj u kojem se dotada natjecao i ne može se plasirati u viši stupanj natjecanja dok traje stečajni postupak. ${ }^{40}$ Ovom odredbom želi se potaknuti klub na pristupanje postupku obveznog preoblikovanja što smo već označili kao posebnu povlasticu klubova-udruga.

34 Pravilnik o nogomentim natjecanjima (Glasnik HNS-a 24/07 - pročišćeni tekst, 09/08, 23/08, 9/09, 10/09-ispravak, 23/09-pročišćeni tekst, 10/10, 15/11, 46/11, 56/11, 19/12, 22/12, 23/12-ispravak, 28/13, 09/14, 15/14, 60/14, 34/15, 28/16 i 51/16 ), dostupan na http://hns-cff.hr/hns/propisi-i-dokumenti/, pregledano 15. XII. 2016.

35 Vidi čl. 61. Pravilnika o nogomentim natjecanjima.

36 Vidi čl. 217. Stečajnog zakona.

37 Vidi čl. 63. Pravilnika o nogometnim natjecanjima. Ipak, to se pravilo ne primjenjuje ako se radi o momčadi mlađih uzrasta kada se uzima da je odustala samo konkretna momčad mlađih uzrasta koja neopravdano nije odigrala dvije utakmice. U takvom slučaju disciplinski odgovaraju klub, momčad koja je odustala i seniorska momčad.

38 Vidi čl. 61a. Pravilnika o nogometnim natjecanjima.

39 Vidi čl. 217. Stečajnog zakona.

40 Vidi čl. 27., čl. 41. i čl. 45. Zakona o sportu te čl. 63a Pravilnika o nogomentim natjecanjima. 
Pravilnik o nogometnim natjecanjima jasno navodi koje su dodatne posljedice otvaranja stečajnog postupka nad klubom: tom klubu oduzima se deset bodova što ih je osvojio u prvenstvu tijekom kojeg je otvoren stečajni postupak, a ako je stečajni postupak otvoren u razdoblju između dvaju prvenstava, klubu će se bodovi oduzeti u sljedećem prvenstvu. ${ }^{41} \mathrm{~S}$ obzirom na konkretne okolnosti kluba, a prvenstveno na sportske rezultate, klubu i njegovim vjerovnicima bilo bi u interesu da se stečajni postupak otvori što je prije moguće ako je stečajni razlog već nastao, a spomenuta sankcija neće bitno utjecati na plasman kluba (ostanak u ligi). S druge strane, postupak otvaranja stečajnog postupka može se i oduljiti, posebice ako se provodi prethodni postupak te postupak ispitivanja gospodarsko-financijskog stanja klubadužnika. ${ }^{42}$ Kako ćemo pokazati u nastavku rada, otvaranje stečajnog postupka ima brojne posljedice po nogometni klub i valja ih pažljivo razmotriti.

Klub koji ne podmiruje svoje obveze iz propozicija natjecanja (primjerice članarinu za igrače) neće biti uključen u novo natjecanje. I ovo pitanje vezuje se uz spominjanu odluku vjerovnika o nastavku poslovanja kluba u stečaju.

Zanimljivu odredbu sadrže Propozicije natjecanja za prvenstvo MAXtv prve lige u kojima se navodi značaj postupka licenciranja klubova uz naznaku da licenca, sukladno odredbama Pravilnika o licenciranju klubova, može biti opozvana tijekom natjecateljske godine ako nogometni klub prekrši bilo koju od svojih obveza iz Pravilnika o licenciranju klubova ili ako klub bude u stečajnom postupku. Opoziv licence znači da se klub više ne može natjecati u ligaškim stupnjevima natjecanja za koje se ista izdaje. Neispunjavanje te obveze, što je manji problem za klub, ujedno predstavlja i prekršaj koji se kažnjava sukladno Disciplinskom pravilniku HNS-a. ${ }^{43}$

Prema Disciplinskom pravilniku HNS-a, ${ }^{44}$ čl. 33., kazna vraćanja u niži natjecateljski stupanj najteža je disciplinska kazna koja se klubu može izreći, a podrazumijeva vraćanje u prvi sljedeći niži stupanj natjecanja. Iznimno, za prekršaj dopinga, prekršaj nagovaranja, podmićivanja i lažiranja i prekršaj sudjelovanja u neregularnosti izreći će se kazna vraćanja u natjecanje niže za dva stupnja. Spomenuta kazna vraćanja u niži stupanj natjecanja provodi se po konačnosti odluke. Ako je natjecanje u tijeku, kažnjeni klub - momčad, ostaje izvan natjecanja do sljedeće natjecateljske godine.

41 Vidi čl. 63b Pravilnika o nogometnim natjecanjima.

42 Vidi čl. 115. i 125. Stečajnog zakona.

43 Vidi čl. 58. Propozicija natjecanja za prvenstvo MAXtv prve lige koje donosi Izvršni odbor Hrvatskog nogometnog saveza temeljem članka 44. Statuta HNS-a (Glasnik 35/15) na sjednici održanoj 06. VII. 2016. Tekst dostupan na http://hns-cff.hr/hns/propisi-i-dokumenti/, pregledano 15. XII. 2016.

Klubovi koji namjeravaju dobiti licencu za sljedeću natjecateljsku godinu obvezni su, sukladno odredbama Pravilnika o licenciranju klubova, podnijeti molbu s pripadajućom dokumentacijom najkasnije do 31. siječnja 2017. godine (za financijske kriterije do 01. travnja 2017.).

44 Disciplinski pravilnik HNS-a je temeljem članka 38. Statuta (Glasnik 16/14) na sjednici održanoj 20. IV. 2015. donijela Skupština Hrvatskog nogometnog saveza, a na sjednicama održanima 22. XII. 2015. i 29. IV. 2016. isti izmijenila i dopunila. Tekst dostupan na http://hns-cff.hr/hns/propisi-i-dokumenti/, pregledano 15. XII. 2016. 
Klub, između ostaloga, može biti kažnjen ako dulje od 30 dana kasni s ispunjavanjem financijskih obveza prema igračima, trenerima i drugim klubovima prema uvjetima utvrđenima ugovorima s igračima, trenerima, odnosno prema ugovoru o transferu, a te obveze nije ispunio niti u dodatnom roku koji mu je ostavio vjerovnik ili ako ne ispunjava kriterije za nastup u natjecanju. ${ }^{45}$

Ako se pokrene postupak za otvaranje stečajnog postupka nad klubom, a tom je klubu prije otvaranja stečajnog postupka izrečena suspenzija zbog neispunjavanja novčanih kazni ili kazna oduzimanja bodova ili negativnih bodova, disciplinsko tijelo koje je donijelo te disciplinske mjere privremeno će ih ukinuti do održavanja prvog ispitnog ročišta. Ako stečajni upravitelj ospori potraživanja vjerovnika zbog kojih je izrečena disciplinska mjera ili ako se na izvještajnom ročištu odluči da se neće nastaviti poslovanje kluba, disciplinsko će tijelo ponovno izreći disciplinske mjere koje su bile ukinute. ${ }^{46}$

Ključan autonomni akt jest ipak Pravilnik o licenciranju klubova Hrvatskog nogometnog saveza. ${ }^{47}$ Riječ je o aktu koji je već izazvao poprilične kontroverze. Najčešći su prigovori na netransparentnost rada Komisije za licenciranje HNS-a te neujednačenost prakse donošenja odluka o licencama.

Proklamirani ciljevi licenciranja klubova su, između ostaloga, poboljšanje ekonomske i financijske sposobnosti klubova, povećanje njihove transparentnosti i vjerodostojnosti, zaštita vjerovnika tako da klubovi pravovremeno podmiruju svoje obveze prema zaposlenicima i državi za poreze i doprinose, te drugim klubovima, uvođenje više discipline i racionalnosti u financijsko poslovanje klubova te poticanje klubova da posluju na osnovi svojih vlastitih prihoda. ${ }^{48}$

Posebno se naglašava okolnost da samo klubovi kojima je izdana odgovarajuća licenca i koji su se kvalificirali na osnovi svojih sportskih rezultata, mogu sudjelovati u natjecanjima licencirane natjecateljske godine.

Davatelj licence jest Hrvatski nogometni savez koji djeluje putem svojih tijela Komisije za licenciranje (koja djeluje kao tijelo prvog stupnja) i Žalbenog tijela za licenciranje (koje djeluje kao tijelo drugog stupnja).

Tražitelj licence može biti samo nogometni klub koji je kao pravna osoba u potpunosti odgovoran za nogometnu momčad koja sudjeluje u međunarodnim klupskim natjecanjima FIFA-e i UEFA-e i u natjecanjima HNS-a, koji je na početku licencirane natjecateljske godine najmanje tri godine registrirani član nadležnog županijskog nogometnog saveza i posredni član HNS-a. Dvojbena je, međutim,

45 Vidi čl. 96. i 97. Disciplinskog pravilnika HNS-a.

46 Vidi čl. 140. Disciplinskog pravilnika HNS-a.

47 Pravilnik donosi Izvršni odbor Hrvatskog nogometnog saveza, na osnovi članka 44. st. 1. točka 6) Statuta HNS-a na svojoj sjednici održanoj 9. prosinca 2015. Statutarna osnova sustava licenciranja kubova Hrvatskog nogometnog saveza bila je definirana Odlukom Skupštine HNS-a o uvođenju i primjeni Uefinog sustava licenciranja klubova donesenoj na sjednici održanoj 27. II. 2003. g., a pravna osnova definirana je čl. 67. Statuta HNS-a. Ovaj Pravilnik također se temelji na Pravilniku UEFA-e o licenciranju klubova i financijskom fair playu. Tekst dostupan na http://hns-cff.hr/hns/propisi-i-dokumenti/, pregledano 15. XII. 2016.

48 Vidi čl. 2. Pravilnika o licenciranju. 
odredba da se svaka promjena pravnog oblika kluba ili pravne strukture grupe (uključujući npr. promjenu sjedišta, naziva ili boje kluba, prijenos vlasničkih udjela između različitih klubova, reorganizaciju, restrukturiranje, spajanje klubova ili razdvajanje klubova) tijekom razdoblja od tri uzastopne godine, a da bi se omogućila njegova kvalifikacija na osnovi sportskog rezultata na štetu integriteta natjecanja i/ ili primitka licence - smatra prekidom članstva što bi za posljedicu imalo da takav klub nije ovlašten biti tražitelj licence. Naime, u već spominjanom Pravilniku o nogometnim natjecanjima propisuje se da prilikom spajanja novoosnovani klub zadržava pravo najbolje plasiranih momčadi (prva momčad, juniori, kadeti, pioniri) posebno za svako natjecanje u kojemu su se natjecale odgovarajuće momčadi spojenih klubova. ${ }^{49}$ Ako se time priznaje kontinuitet, onda i u slučaju spajanja novom klubu treba izdati licencu. Svakako bi Savez i njegova tijela trebali razjasniti pojam ,integritet natjecanja“. To pogotovo stoga što se na razini licence UEFA-e predviđa da UEFA može odobriti izuzeće od pravila ,tri godine“ “. ${ }^{50}$

Sam postupak licenciranja složen je i odvija se u više faza, pri čemu klubovi moraju ispuniti brojne kriterije, razvrstane u glavne skupine, i to kao sportski, infrastrukturni, kriteriji administracije i stručnog osoblja, pravni i financijski. Za temu ovoga rada potrebno je dati osvrt posebice na posljednja tri kriterija. $\mathrm{U}$ kriterijima administracije navodi se kao obvezna stavka da klub ima ,glavnog direktora" koji je odgovoran za vođenje svakodnevnog poslovanja tražitelja licence. Prava i obveze glavnog direktora opisani su u aktima tražitelja licence, iz kojih je vidljivo da ista osoba zastupa tražitelja licence i preuzima odgovornost tražitelja licence za ispunjenje uvjeta iz zahtjeva za licenciranje. Glavni direktor mora biti imenovan najmanje do završetka licencirane natjecateljske godine. ${ }^{51}$ Prema Stečajnom zakonu, funkciju organa društva-kluba preuzima stečajni upravitelj pa bi traženi kriterij zapravo postao eliminacijski i klub ne bi mogao dobiti licencu. Stoga bi bilo nužno spomenuti kriterij razraditi za slučaj otvaranja stečajnoga postupka. Stečajni upravitelj u tom kontekstu zastupa klub-tražitelja licence pa će on biti dužan HNS-u dostaviti bitne dokumente i dati odgovarajuće izjave. Ipak u pojmovniku koji se nalazi u dodatku spomenutog Pravilnika, Savez daje svoju definiciju stečajnog postupka te navodi da je to dobrovoljni ili obvezni postupak koji može služiti kao alternativa likvidaciji pravnog subjekta a često je poznat kao i otvaranje stečaja (?). Svakodnevno upravljanje djelatnostima subjekta u stečaju u ime vjerovnika obavlja stečajni upravitelj. Također se daje definicija instituta „Zaštita od vjerovnika“ gdje se navodi da su to postupci zasnovani na zakonima ili pravilnicima čiji je cilj pravni subjekt zaštititi od vjerovnika, spasiti nesolventne subjekte i omogućiti im nastavak poslovanja s vremenskom neograničenošću. Ovi postupci obuhvaćaju stečajne i druge slične postupke (koji mogu rezultirati kompromisom s vjerovnicima, stečajem ili likvidacijom). Iz navedenoga bi se na prvi pogled moglo zaključiti da Pravilnik HNS-a priznaje pojavnost stečaja te da

49 Usp. čl. 13. Pravilnika o licenciranju te čl. 62. Pravilnika o nogomentim natjecanjima.

50 Vidi Dodatak I. Pravilnika UEFA-e o licenciranju klubova i financijskom fair playu. Pravilnik dostupan na http://hns-cff.hr/hns/propisi-i-dokumenti/, pregledano 15. XII. 2016.

51 Vidi glavu III. Administrativni kriteriji, kriterij A.02. Pravilnika o licenciranju. 
dopušta mogućnost stjecanja licence i onda kada se nad klubom otvori stečajni postupak iako to negira kroz druge odredbe. Tako se, primjerice, $\mathrm{u}$ istom Pravilniku navodi da se godišnji financijski izvještaji pripremaju s pretpostavkom da tražitelj licence može nastaviti vremenski neograničeno poslovati, što znači da će nastaviti svoje poslovanje u doglednoj budućnosti, a pretpostavlja se da tražitelj licence nema namjeru, ni potrebu, za likvidacijom, prestankom poslovanja ili traženjem zaštite od vjerovnika u skladu s relevantnim zakonima $\mathrm{RH} .{ }^{52}$ Kako protumačiti izričaj da klub nema namjeru ni potrebu predložiti otvaranje stečajnog postupka?

U Glavi V. Pravilnika razrađuju se na prvi pogled strogi i složeni finacijski kriteriji. Tražitelj licence dužan je dostaviti godišnje finacijske izvještaje, prema Zakonu o računovodstvu ${ }^{53}$ i Zakonu o trgovačkim društvima. ${ }^{54}$ Stoga se računovodstveni standardi koji vrijede za društva kapitala primjenjuju i onda kada je tražitelj licence klub-udruga.

Kriterij koji klub u stečaju kao tražitelj licence nerijetko ne može ispuniti jest taj da mora dokazati da na dan 31. ožujka, koji prethodi licenciranoj natjecateljskoj godini, nema dospjelih obveza prema nogometnim klubovima koje proizlaze iz djelatnosti prijelaza igrača (transfera) obavljenih prije prethodnog 31. prosinca. $^{55}$ No ipak, zamisliv je i slučaj da je nad klubom stečajni postupak otvoren zbog obveza koje ne proizlaze iz djelatnosti transfera igrača pa bi klub mogao ispuniti i taj kriterij. Valja napomenuti da obveze nisu samo oni iznosi koji se duguju nogometnim klubovima kao rezultat djelatnosti transfera i koji uključuju naknadu za treniranje igrača i solidarne doprinose, kako je regulirano Pravilnikom FIFA-e o statusu i transferima igrača, nego i svi oni iznosi koji se duguju s osnova ispunjenja određenih uvjeta. ${ }^{56}$ Nogometni klubovi kod nas često se pozivaju na postojanje okolnosti zbog koje se obveza ne smatra dospjelom. Klub-tražitelj licence mora dokazati da je zaključio pisani sporazum kojim je vjerovnik prihvatio produljenje roka plaćanja nakon ugovorenog roka ili je,

u svezi s dospjelim obvezama što proizlaze iz transfera, podnio pravni zahtjev koji nadležno tijelo, sukladno nacionalnom zakonodavstvu smatra dopuštenim, ili je pokrenuo postupke pred nadležnim nacionalnim ili međunarodnim nogometnim tijelima ili relevantnim arbitražnim sudom, a obveza se ne smatra dospjelom niti onda kada je klub-tražitelj licence osporio pred nadležnim tijelom, u skladu s nacionalnim zakonima, nacionalnim ili međunarodnim nogometnim tijelima,

52 Vidi čl. V. 3. Pravilnika o licenciranju.

53 Zakon o računovodstvu, Narodne novine 78/2015, 134/2015, 120/2016.

54 Zakon o trgovačkim društvima, Narodne novine 111/1993, 34/1999, 121/1999, 52/2000, 118/2003, 107/2007, 146/2008, 137/2009, 111/2012, 125/2011, 68/2013, 110/2015.

55 Vidi čl. V.16. Pravilnika o licenciranju.

56 Sporazumi između klubova o transferu registracije igrača mogu uključivati i odredbe za buduće plaćanje naknada koje ovise o ispunjavanju određenih uvjeta u nekoj kasnijoj fazi u budućnosti (tj. nepredvidljive obveze). Uobičajeno se takve odredbe odnose na budući 'uspjeh' odnosnog igrača i/ili novog kluba za koji igra - primjerice: broj nastupa, broj postignutih pogodaka, međunarodni nastupi, napredovanje kluba, izbjegavanje nazadovanja, kvalifikacije u natjecanjima UEFA-e itd. Dok određeni uvjet nije stvarno zadovoljen, pripadajuća obveza nije plativa i ne može biti dospjela. 
ili relevantnim arbitražnim sudom, podneseni zahtjev ili postupke koje je u svezi s dospjelim obvezama pokrenuo vjerovnik i može razumno uvjeriti tijela za licenciranje HNS-a da ima osnovane razloge za osporavanje tog zahtjeva ili pokrenutog postupka odnosno klub može razumno uvjeriti tijela za licenciranje HNS-a da je poduzeo sve raspoložive mjere kako bi utvrdio i platio klubu vjerovniku naknadu za treniranje i solidarni doprinos (kako je regulirano Pravilnikom FIFA-e o statusu i transferima igrača). ${ }^{57}$ Vidljivo je da bi klubovi često mogli isticati prigovor nedospjelosti obveze, a s druge strane izričaj „ako klub može razumno uvjeriti Davatelja licence..." ostavlja prostora za različita tumačenja, što za posljedicu ima pravnu nesigurnost. Isti zaključak vrijedi i za kriterij prema kojemu klub koji aplicira za licencu mora dokazati da nema nepodmirenih obveza prema zaposlenicima niti prema državi s osnove doprinosa i poreza. Zaposlenicima kluba smatraju se svi profesionalni igrači, sukladno važećem Pravilniku FIFA-e o statusu i transferima igrača i Pravilniku o statusu igrača i registracijama HNS-a, administrativno, stručno, medicinsko i sigurnosno osoblje te svi ostali zaposlenici koji imaju zaključen ugovor o radu s klubom-tražiteljem licence. Obveze su sve vrste naknade koje su plative zaposlenicima u odnosu na ugovorne ili zakonske obveze, uključujući plaće, dohotke, plaćanja za prava na imidž, bonusi i ostala davanja, ali i obveze prema osobama koji više nisu zaposlenici kluba. U oba prethodna slučaja, licenca se mora uskratiti ako se pokaže da klub ima nepodmirenih obveza prema spomenutim subjektima. Teško je zamisliti slučaj da država pristane na odgodu svojih tražbina, tako da u slučajevima kada se ne provodi obvezno preoblikovanje kluba, Davatelj bi klubu trebao uskratiti licencu. U slučaju uskrate licence zbog navedenih razloga, klub de facto sljedeće sezone ima pravo nastupa tek u 4 . ligi.

Nadalje, tražitelj licence mora sedam dana prije roka za donošenje odluke o licenci dostaviti Komisiji za licenciranje HNS-a posebna očitovanja koja su od ključne važnosti za problem stečaja. Naime, tražitelj licence mora potvrditi jesu li ili nisu nastali neki događaji ili stanja od ključnog ekonomskog značaja koji mogu imati negativan utjecaj na financijski položaj tražitelja licence od datuma bilance iz prethodnih (revidiranih) godišnjih financijskih izvještaja. Ako su nastali takvi događaji ili stanja, pisano očitovanje uprave tražitelja licence mora sadržavati opis prirode događaja ili stanja, te procjenu njegova financijskog učinka.

Nadalje, tražitelj licence mora iskazati je li tražio ili dobio zaštitu od svojih vjerovnika sukladno zakonima ili propisima. Kako je već istaknuto, tu spada i stečajni postupak. Događaji ili stanja koji se, pojedinačno ili skupno, mogu smatrati od ključnog ekonomskog značaja, primjerice su posudba s fiksnim rokom čije se dospijeće približava bez realnih izgleda produljenja ili otplate, naznake povlačenja financijske potpore financijera i ostalih vjerovnika, znatni poslovni gubici od zadnjih predanih financijskih izvještaja, nemogućnost plaćanja vjerovnicima na dan dospijeća, nemogućnost zadovoljavanja uvjeta iz ugovora o zajmovima zaključenih s dobavljačima financijskih sredstava, odluka uprave o namjeri likvidacije subjekta,

57 Vidi čl. V. 18. Pravilnika o licenciranju. Međutim, ako tijela za licenciranje HNS-a koja donose odluke smatraju da je takav pravni zahtjev podnesen ili da su ovi postupci pokrenuti s isključivom svrhom izbjegavanja rokova (tj. da bi „kupio“ vrijeme), relevantni iznos će se i dalje smatrati dospjelom obvezom. 
prestanku poslovanja ili traženju zaštite od vjerovnika u skladu sa zakonima i propisima, ili zaključak uprave da nema realne alternative osim da tako učini. ${ }^{58}$ Naglašava se, međutim, da postojanje jednog ili više spomenutih događaja ne znači da uvijek postoji negativan utjecaj na financijski položaj tražitelja licence. To opet znači da tijela HNS-a kao davatelja licence imaju slobodu prosudbe o tome može li klub, temeljem svih financijskih parametara te posljednjih izvještaja o novim događajima i okolnostima, nastaviti vremenski neograničeno poslovati najmanje do kraja licencirane natjecateljske godine. Iz navedenog proizlazi da pojam „neograničenog poslovanja“ treba shvatiti u užem smislu - samo za sljedeću natjecateljsku sezonu. Izgleda da takvog manevarskog prostora nema kada je predmet zahtjeva licenca UEFA-e. Naime, ta licenca mora se uskratiti ako u razdoblju od 12 mjeseci koji prethode licenciranoj natjecateljskoj godini tražitelj licence traži ili je dobio i još uvijek prima zaštitu od svojih vjerovnika, sukladno relevantnim zakonima i propisima. Da bi se izbjegla sumnja, licenca se također mora uskratiti čak i ako u trenutku kada se donosi odluka o licenci klub više ne prima zaštitu od vjerovnika.$^{59}$ Drugim riječima, ako je nad klubom otvoren stečajni postupak u tom razdoblju, klub ne može dobiti licencu za sudjelovanje u natjecanjima UEFA-e.

Iz svega navedenoga, vidljivo je da postoje brojni problemi međudjelovanja odredaba stečajnog prava i autonomnih pravila HNS-a koja ostavljaju velik prostor za arbitrarnost u procjeni je li konkretan klub ispunio uvjete za stjecanje licence. ${ }^{60}$ Pridržavamo li se strogo odredaba Pravilnika, vidljivo je da klub nad kojim je otvoren stečajni postupak ne bi mogao ostvariti pravo na licencu za natjecanja pod okriljem UEFA-e niti za natjecanje u našoj prvoj, drugoj i trećoj ligi. Primjetno je da HNS i njegova tijela imaju arbitraran pristup u odlučivanju o dodjeli licence nogometnim klubovima. Da bi se otklonile dvojbe u budućnosti, valja preporučiti da se u spomenutom Pravilniku jasno naznači smije li tražitelj licence biti klub u stečaju odnosno valja razraditi odredbu prema kojoj bi, primjerice, tražitelj licence mogao biti klub kojem je potvrđen stečajni plan, a sud je donio rješenje o zaključenju stečajnog postupka.

S druge strane, zbog duljine rokova u stečajnim postupcima, nije realno očekivati da se postupak stečaja sa stečajnim planom otvori i uspješno okonča između dviju natjecateljskih sezona. Naime, čak i ako nije pokrenut prethodni postupak, sud će

58 Vidi čl. V. 30. i 31. Pravilnika o licenciranju.

59 Vidi čl. V. 33. Pravilnika o licenciranju.

60 Vidi primjerice slučaj HNK Gorica. Vijeće športske arbitraže pri HOO-u 22. ožujka 2012. donijelo je rješenje po tužbi HNK Gorica, a protiv odluke Arbitraže HNS-a od 30. rujna 2011. Rješenjem po broju predmeta 20/11-VŠA poništava se odluka Izvršnog odbora HNS-a od 20. VI. 2011. U obrazloženju odluke navodi se: ,'Vijeće športske arbitraže utvrđuje da je odluka IO HNS-a ništavna od trenutka donošenja, pravno se smatra nepostojećom i kao takva nije smjela proizvesti ni stvarne ni pravne posljedice". VSA nadalje u obrazloženju govori kako, zbog tako izričitih odredaba Pravilnika o licenciranju klubova, koji je donio upravo sam IO HNS-a, pravno nije moguće objasniti zašto je taj isti IO HNS-a uzurpirao ovlast tijela koju mu je sam propisao te neovlašteno i protupropisno donio odluku od 20. VI. 2011." Prema ocjeni HOO-a, IO HNS-a je donošenjem odluke od 20. VI. 2011. kao nenadležno tijelo grubo povrijedio Statut HNS-a i Pravilnik o licenciranju klubova. U to vrijeme u klubu se ozbiljno razmišljalo da se putem Zakonskih mogućnosti stavi privremena zabrana upravljanja kompletnom imovinom i financijskim sredstvima Hrvatskog nogometnog saveza sve do konačnog okončanja postupka. 
odrediti ročište radi rasprave o pretpostavkama za otvaranje stečajnog postupka najkasnije u roku od 30 dana od podnošenja prijedloga za otvaranje stečajnog postupka. ${ }^{61} \mathrm{Kad}$ sud donese rješenje o otvaranju stečajnog postupka, dopušteno je izraditi stečajni plan, ali se pri tom ne smije zaboraviti na rok od 60 dana u kojem vjerovnici moraju prijaviti svoje tražbine. Nadalje, ako stečajni plan nije odbačen, a ne radi se o slučajevima gdje je potrebno prethodno očitovanje, zakazuje se ročište koje se mora održati u roku od 30 dana od zakazivanja. ${ }^{62}$ Ako se i usvoji odluka, mora još proteći i rok za žalbu. Iz prakse naših stečajnih postupaka posve je jasno kako nije razumno očekivati da se tako opsežan postupak okonča u relativno kratkom roku pa i uz maksimalnu kooperativnost svih sudionika, a posebice vjerovnika kluba, što se pokazalo u slučaju NK Split koji je primjer uspješne provedbe postupka stečajnog plana, ali sam postupak trajao je mnogo godina.

\section{ZAKLJUČNA RAZMATRANJA}

Iz prethodne rasprave jasno proizlazi da na području pravnog uređenja nogometne igre, a u svezi sa stečajem nogometnog kluba, postoji velika pravna nesigurnost. Tom stanju nisu pomogli ni Zakonodavac niti Savez kao donositelj autonomnih akata. Mogućnost preoblikovanja sportske udruge, kod koje je nastao stečajni razlog, u sportsko dioničko društvo, predstavlja dobro rješenje s obzirom na posebnost sporta, ali u kontekstu rasprave o stečaju stoji nepobitna činjenica da se radi o pravnom subjektu nad kojim bi, da nije riječ o sportskom klubu-udruzi, bio otvoren stečajni postupak. Ako se klubu omogućilo preoblikovanje a da mu u međuvremenu nije uskraćena licenca za natjecanje, onda to treba primijeniti i na klubove u stečaju, posebice onda kada je klub na putu usvajanja stečajnog plana. Savez stoga mora svoje akte prilagoditi činjenici da je klub nad kojim je otvoren stečaj još uvijek pravni subjekt kojemu treba omogućiti nastavak djelatnosti, ako su tako odlučili vjerovnici. Glavna djelatnost nogometnih klubova jest sudjelovanje u sportskim natjecanjima. Uskrata licence stoga bi predstavljala mjeru koja bi mogla biti suprotna temeljnim načelima na kojima počiva stečajni postupak.

Predmet posebnog rada mogla bi biti i odredba da Savez ima pravo primiti naknadu za treniranje koja bi u načelu trebala biti plaćena jednom od njegovih pridruženih klubova, ako on može dokazati da je odnosni klub - za koji je profesionalac bio registriran i koji ga je trenirao - u međuvremenu prestao sudjelovati u organiziranom nogometu i/ili više ne postoji zbog, posebice, stečaja, likvidacije, raspuštanja ili gubitka članstva. Naime, u spominjanom slučaju igrača Marka Roga, NK Varteks još uvijek postoji kao pravni subjekt, doduše u stečaju. Uza sve uvažavanje autonomnih pravila Saveza i UEFA-e, opravdano se pitamo što je s pravima stečajnih vjerovnika? Da je riječ o subjektu koji nije nogometni klub, spomenuta sredstva bila bi raspoređena vjerovnicima prema odredbama Stečajnog

\footnotetext{
61 Vidi čl. 128. Stečajnog zakona.

62 Vidi čl. 321. Stečajnog zakona.
} 
zakona. Čak i da je postupak okončan, a stečajni dužnik brisan iz registra, mogao bi se primijeniti institut naknadne diobe.

Sveukupno uzevši, prema sadašnjem stanju stvari, jezično tumačenje akata Saveza ne ostavlja nam prostora za ona subjektivna ciljna tumačenja koja Savez svake sezone primjenjuje u postupku licenciranja klubova. Za održivo poslovanje klubova zasigurno nije dobro rješenje da se zbog postupka ishođenja licence svake godine dodatno zadužuju, osporavaju utemeljene tražbine vjerovnika (da bi ih se oglasilo nedospjelim), da dogovaraju odgodu plaćanja ili da njihovi zastupnici, uz rizik kaznene i materijalne odgovornosti, po zakonu ne prijavljuju nastanak stečajnog razloga. Takvo postupanje upravo je suprotno ciljevima koje je UEFA imala na umu kod donošenja Pravilnika o licenciranju i ostalih akata što ih je usvojio i naš Savez. Posebno se ističe kako se Pravilnikom želi osigurati adekvatna razina poslovodstva i organizacije, očuvanje integriteta i nesmetanog odigravanja natjecanja UEFA-e i HNS-a, kako se klubovima želi omogućiti razvijanje sustavnog vrednovanja u financijskim i pravnim kriterijima, te poboljšanje ekonomske i financijske sposobnosti. Stoga kroz konkretne odredbe treba jasno urediti pitanje natjecateljskog statusa kluba u stečaju, posebno vodeći računa o slučajevima kada vjerovnici kluba žele nastavak obavljanja sportske djelatnosti.

\section{SOME ISSUES RELATED TO BANKRUPTCY OF FOOTBALL CLUBS IN THE REPUBLIC OF CROATIA}

Bankruptcy of football clubs, like all sports clubs in the Republic of Croatia, has become a burning issue due to the enormous number of cases when clubs, acting under the legal form of an association or as a sports joint stock company, have become over indebted or unable to pay. This topic in particular arouses interest because, although it concerns recognisable legal forms governed by appropriate laws, they should be to a certain extent separated. This is because the Sports Act is first applicable to them and then secondly regulations which regulate material bankruptcy and regulations which regulate such associations. In this problem area, an important role is held by autonomous rules, international and national, which in several places regulate the issue of the legal position of a club in crisis. In our country, their contributor is the Croatian Football Federation (HNS), exclusively, the only national sports federation which promotes and cares for Croatian football and represents it in international relations. In this sense, together with HNS's statute, an important role is held by HNS's rulebook on licensing clubs, the rulebook on football competitions, rulebook on the status of football players and registration, HNS's disciplinary rulebook and numerous other acts. At an international level, the creator of autonomous rules is the International Football Federation (FIFA) that is European Football Union (UEFA). Given this, what is going on with football clubs when they become unable to pay or over indebted should be examined. Undoubtedly, most answers can be found in the provisions of the Bankruptcy Act, but it is necessary to investigate what the coexistence of national and autonomous laws in this issue is like. The issue of bankruptcy is not only limited to sports (football) clubs, but also to sports federations as the bearers of competitions which have the legal status of an association and as such can also become the subjects of bankruptcy. This last issue is far from harmless because in the territory of country 
Dr. sc. Ratko Brnabić: Neka pitanja u svezi sa stečajem nogometnih klubova u Republici Hrvatskoj Zbornik radova Pravnog fakulteta u Splitu, god. 54, 2/2017., str. 437.- 456.

there can only be one main sports organisation. If bankruptcy is commenced over this creation, how can sports competitions be held? Mentioned also are many other issues raising doubts in practice to which it is not always possible to provide a singular answer. In this paper, analysis of autonomous sources of law is principally carried out, in particular of these provisions which prescribe particular additional legal effects in cases where bankruptcy proceedings are commenced over football clubs. This points to certain provisions of HNS' rulebook on licensing, faithful application of which could have serious consequences for clubs in financial crisis.

Key words: bankruptcy, association, sports company with share capital, licensing clubs, bankruptcy plan 